施設入所高齢者の ADL 維持に要する亜鉛およびたんぱく質の 栄養状態の Geriatric Nutritional Risk Index による評価

\author{
小坂和江 $*$ ・濱㟝絵梨** - 小西吉裕 ${ }^{* * *} \cdot$ 山下佐知子**** \\ 安藤千夏 $* * *$. 遠藤順朗 $* * * *$. 谷口啓子 $* * * *$ ・菊永茂司 $* *$ \\ （*美作大学, **ノートルダム清心女子大学, ***国立病院機構鳥取医療センター, \\ ****老人保健施設勝央苑, $* * * * *$ 美作市立作東老人保健施設) \\ (平成27年 2 月 2 日受付, 平成 27 年 5 月 1 日受理)
}

\title{
Evaluation by the Geriatric Nutritional Risk Index of the zinc and protein nutritional status required for the Activities of Daily Living maintenance in the institutionalized elderly
}

Kazue Kosaka *, Eri Hamasaki **, Yoshihiro Konishi ***, Sachiko Yamashita****, Chinatsu Ando****, Yoriaki Endo *****, Keiko Taniguchi ${ }^{* * * * *}$, Shigeshi Kikunaga**

* Mimasaka University, 50, Kitazono-cho, Tsuyama-shi, Okayama, 708-8511

** Notre Dame Seishin University, 2-16-9, Ifuku-cho, Kita-ku, Okayama-shi, Okayama, 700-8516

*** National Tottori Medical Center, 876, Mitsu, Tottori-shi, Tottori, 689-0203

**** Health Facility, Shououen, 242-1, Taira, Shoo-cho, Katsuta-gun, Okayama, 709-4344

***** Health Facility, Sakuto, 280, Emi, Mimasaka-shi, Okayama, 709-4234

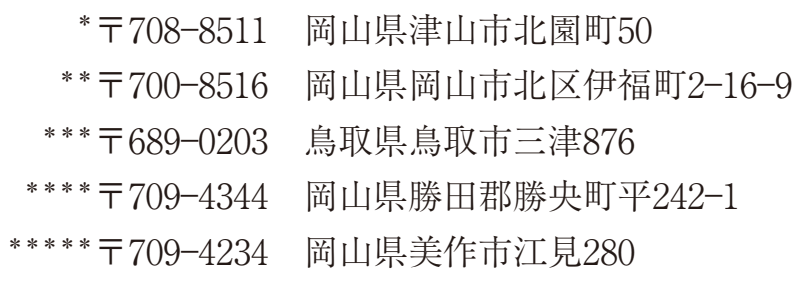

The purpose of this study of the institutionalized elderly was to examine two relationships using the Geriatric Nutritional Risk Index (GNRI); one between the zinc nutritional status and the Activities of Daily Living (ADL), and the other between the protein nutritional status and ADL. The estimations of the hematological constituents, body index, and dietary survey were made based on the two examinations carried out on a group of 21 elderly patients ( 3 male, 18 female, mean age $83 \pm 7$ years; survey 1 ) and another group of 26 elderly patients ( 6 male, 26 female, mean age $90 \pm 6$ years : survey 2).

The results from this study are summarized as follows :

1) Compared to the no risk and low risk, the moderate risk and major risk groups of GNRI showed significantly lower levels of body weight, Body Mass Index (BMI), Basal Metabolic Rate (BMR), serum Alb, TP, and zinc values.

2) Compared to the no risk and low risk, the moderate risk and major risk groups of GNRI showed significantly higher levels of the level of care, the grade of bedriddenness, and grade of cognitive function. 
3) Significant positive correlations were found between the GNRI value and 8 other values; body weight, BMI, BMR, serum Alb, TP, A/G ratio, iron, and zinc. On the other hand, significant inverse correlations were found between the GNRI value and 3 other values; the level of care, the grade of bedriddenness, and grade of cognitive function.

4) The values calculated from the regression equation indicated that the low risk of GNRI exceeded the reference value of the BMI, serum TP, Alb, A/G ratio and zinc values.

These results indicate that the GNRI is a reliable tool for the evaluation of the zinc nutritional status. In addition, the GNRI is also reliable for the evaluation of seven factors which are subject to change according to the zinc nutritional status; the level of care, the grade of bedriddenness, the grade of cognitive function, BMI, serum TP, Alb values, and $A / G$ ratio.

\section{1. 緒言}

わが国の高齢者の人口割合は，将来推計人口によると， 平成 22 年が $23.0 \%$, 平成32年が $29.1 \%$, 平成 42 年が $31.6 \%$, 平成52年が $36.1 \%$, 経年的に急激に増加すると予測さ れている ${ }^{1)}$ 。この高齢者の QOL 維持と健康寿命の伸長 は重要な社会問題となっている。

高齢者の栄養評価法には, SGA(Subjective global Assessment $)^{2)}$, MIS (Malnutrition Inflammation Score) ${ }^{3)}$ MNA-SF (Mini Nutrition Assessment-Short Form) ${ }^{4}$, NRS(Nutrition Risk Score) ${ }^{5)}$, MUST(Malnutrition Universal Screening Tool) ${ }^{6}$, GNRI(Geriatric Nutritional Risk Index $)^{7)}$, MST (Malnutrition Screening Tool ${ }^{8)}$ がある。 Yamada らは, これらの評価法を血液透析患者に適応し， GNRI が最も優れた栄養スクリーニング法であったと報 告した ${ }^{9)}$ 。また, GNRIは, 高齢者の筋肉障害 ${ }^{10-11)}$ や合 併症のリスク ${ }^{7,12)}$, 在院日数 ${ }^{13)}$, 死亡率 $\left.{ }^{7}, 9,12,14,15\right)$ と相 関することが示されており，高齢者の有用な栄養評価法 として推奨されている ${ }^{12,16-19)}$ 。

一方，高齢者の多くに亜鉛不足が観察されている ${ }^{20-23)}$ また，施設入所高齢者は血清亜鉛值が低く ${ }^{24,25)}$ ，亜鉛欠乏 状態にあると報告されている ${ }^{20,23,26,27)}$ 。高齢者に亜鉛が欠 そすると, 食欲不振 ${ }^{28)}$, 創傷治癒遅延 ${ }^{28)}$, 神経障害 ${ }^{29,30)}$ 易感染症 ${ }^{31}$ ， $\mathrm{ADL}$ 低下 ${ }^{32}$ ，生存率低下 ${ }^{32}$ ，味覚異常の発

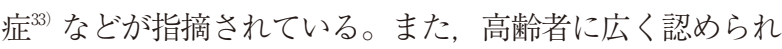
る栄養上の問題として PEM (Protein Energy Malnutrition) がある ${ }^{34-36)}$ 。高齢者の PEM は，免疫応答の低下 ${ }^{37-43)}$, 在院 日数の延長 ${ }^{44)}$, 感染症リスクの増大 ${ }^{45)}$, 合併症の増加 ${ }^{46)}$, $\mathrm{ADL}$ の低下 ${ }^{47)}$, 死亡率の増加 ${ }^{48}$ の原因となることが知ら れている。そして，高齢者の PEM では常に亜鉛欠乏が 認められている ${ }^{21,37,42)}$ 。このことは, 高齢者の亜鉛欠乏 で観察される症状が，上記の高齢者の PEM で発現する 症状ときわめて類似していることからも董付けられる。

このように，亜鉛が PEM の発症に密接にかかわって いることから, PEMの改善にはたんぱく質やエネル ギーの補給39,49-51) に加えて, 亜鉛の栄養状態の改善が必
要であることを示唆している。

著者らは，施設入所高齢者を対象にして，血清覀鉛值 とたんぱく質栄養や鉄栄養の指標との間に正の相関を示 し ${ }^{52}$, これらの成分值は, 軽い要介護度（要介護度 1,2 3 ）の対象者は重い要介護度（要介護度 4，5）の者に 比して高く，さらにBMI18.5以上の対象者は 18.5 未満 の者に比して高いことを見出した ${ }^{53)}$ 。また，亜鉛の栄養 状態によって BMI, ADLの判定要因となる要介護度, 寝たきり度, 認知度が変動することを見出した ${ }^{54)}$ 。これ らの結果は, 亜鉛の栄養状態の改善によって高龄者の低 栄養状態・PEM が好転し, ADL と QOL が向上する可 能性を示唆している。

そこで，高齢者の亜鉛の栄養状態の改善，およびたん ぱく質栄養状態の好転とADLの向上を導く栄養処方の 論理的な判断指標を得るために, 亜鉛の栄養状態で変化 し, ADL を決定する要因でもある血清アルブミン值, BMI，寝たきり度，認知度を GNRI で疫学的に評価した。 そして，ADLを良好に維持するその值の設定を試みた。

\section{2. 方 法}

\section{(1) 調査対象者と調査期間}

1) 調 査 1

対象者は, 特別養護老人ホーム 1 施設に入所中の要介 護高齢者で, 延べ人数は21名（男性 3 名, 女性18名）で あった。調査は, 2006年 6 月 1 日から 12 月31日の半年間 に, 対象者に対して $1 \sim 2$ 回行った。GNRI 值は, Bouillanne $ら^{7)}$ の次の式から求めた。GNRI $=[1.489 \times$ 血清アルブミン $(\mathrm{Alb})$ 值 $(\mathrm{g} / \mathrm{dL}) \times 10]+[41.7 \times[$ 測定体 重 $(\mathrm{kg}) \div$ 理想体重 $(\mathrm{kg})]]$ である。なお, 理想体重 $(\mathrm{IBW})$ は, Bouillanne $ら^{7)}$ に従い Lorents の式(男性：身長 $(\mathrm{cm})$ $-100-([$ 身長 $(\mathrm{cm})-150] \div 4)$, 女性：身長 $(\mathrm{cm})-100$ - ([身長 $(\mathrm{cm})-150] \div 2.5))$ で求めた。対象者の属性は, table 1 に示した。年齢の平均值は, $83 \pm 7$ 歳（男性76歳 女性84歳）であった。対象者の身体計測は, 次の方法で 行った。体重は車椅子用体重計を用い, 身長はメジャー を用いた 5 点法 ${ }^{55)}$ でそれぞれ計測した。また，要介護度 
Table 1 Characteristic of the subjects

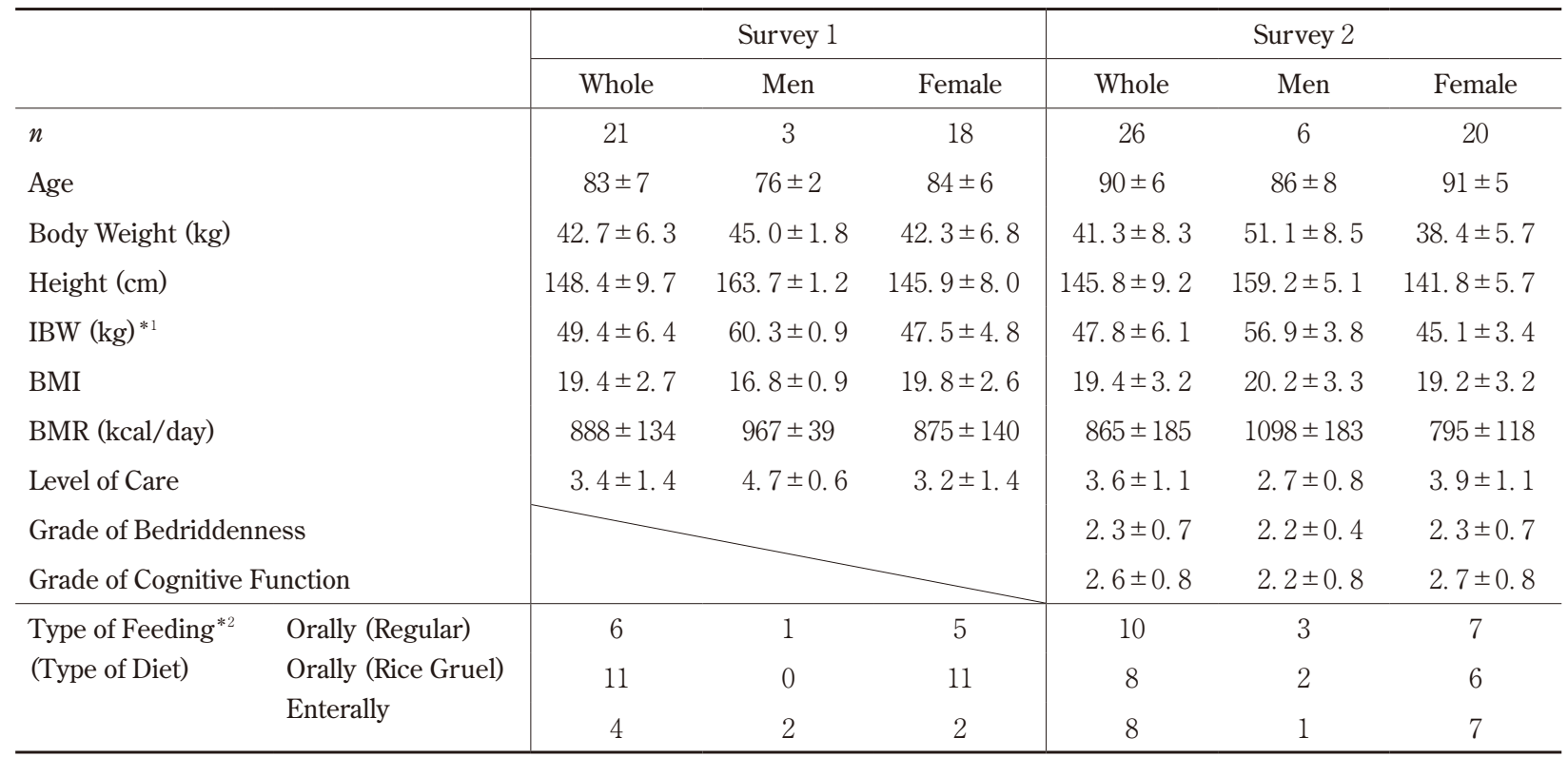

Each values is mean $\pm \mathrm{SD}$.

* 1 The values show Ideal Body Weight(IBW). The IBW values calculeted according to the Lorents formula.

(Men: Height $(\mathrm{cm})-100-([$ Height $(\mathrm{cm})-150] \div 4)$, Female: Height $(\mathrm{cm})-100-([$ Height $(\mathrm{cm})-150] \div 2.5)$ )

$* 2$ The values show the numbers of type of feeding and type of diet.

は，診療録より確認した。なお，要介護度は，わが国の 介護保険制度によって要介護認定審査会で決定されてい $3^{56)}$ 。

調查開始時の体格の平均値は，体重 $42.7 \pm 6.3 \mathrm{~kg}$ （男 性 $45.0 \mathrm{~kg}$ ，女性 $42.3 \mathrm{~kg}$ )，身長 $148.4 \pm 9.7 \mathrm{~cm}$ （男性 $163.7 \mathrm{~cm}$, 女性 $145.9 \mathrm{~cm}$ ), IBW は $49.4 \pm 6.4 \mathrm{~kg}$ (男性 $60.3 \mathrm{~kg}$, 女性 $47.5 \mathrm{~kg}$ )，BMI19.4 2.7 (男性 16.8 , 女 性19.8）であった。基礎代謝量（BMR）は，性別およ び年齢別の基礎代謝基準值に対象者の体重を乗じて算出 し, その平均值は, $888 \pm 134 \mathrm{kcal} /$ 日（男性 $967 \mathrm{kcal} /$ 日， 女性 $875 \mathrm{kcal} /$ 日）であった。また，要介護度の平均值 は3.4 1.4（男性4.7, 女性3.2）で, 対象者の栄養補給 法は, 経口栄養法が17名（男性 1 名, 女性16名), 経腸 栄養法が 4 名（男性 2 名, 女性 2 名）であった。経腸栄 養者の栄養片は, CZ-Hi (森永乳業株式会社) ${ }^{57}$ )であった。

\section{2 ) 調 査 2}

対象者は，老人保健施設 2 施設に入所中の要介護高齢 者26名（男性 6 名，女性20名）である。調査は, 2011年 11月14日から12月13日までの 1 か月間に 1 回行った。対 象者の属性は, table 1 に示した。年齢の平均值は, 90 \pm 6 歳（男性86歳，女性91歳）であった。調査 1 と同様 の身体計測項目は, 調査 1 と同じ手法で行った。対象者 の寝たきり度と認知度は, 日常生活自立度判定基準 ${ }^{58)}$ と 認知症である老人の日常生活自立度判定基準 ${ }^{58)}$ に基づい て判定されている。寝たきり度と認知度のランクは，介 護の必要度が高まるほど数值が大きくなるように点数化 した。具体的には，寝たきり度は，ランク A を 1 点, ランク $\mathrm{B}$ を 2 点, ランク $\mathrm{C}$ を 3 点として点数化した。
認知度は, ランク I を 1 点, ランク II 2 点, ランク III を 3 点, ランク IVを 4 点として点数化した。

調査開始時の体格の平均值は, 体重 $41.3 \pm 8.3 \mathrm{~kg}$ （男 性 $51.1 \mathrm{~kg}$, 女性 $38.4 \mathrm{~kg}$ ), 身長 $145.8 \pm 9.2 \mathrm{~cm}$ (男性 $159.2 \mathrm{~cm}$, 女性 $141.8 \mathrm{~cm}$ ), IBW は $47.8 \pm 6.1 \mathrm{~kg}$ (男性 $56.9 \mathrm{~kg}$ ，女性 $45.1 \mathrm{~kg}$ ), BMI19.4 \pm 3.2 (男性20.2, 女 性19.2）であった。BMRの平均值は，865 $\pm 185 \mathrm{kcal} /$ 日（男性1, $098 \mathrm{kcal} /$ 日, 女性 $795 \mathrm{kcal} /$ 日, 要介護度の 平均值は3. $6 \pm 1.1$ (男性2.7, 女性3.9）であった。寝た きり度の平均值は， $2.3 \pm 0.7$ (男性 2.2 , 女性 2.3 ), 認 知度の平均值は, $2.6 \pm 0.8$ (男性 2.2 , 女性 2.7 ) であっ た。対象者の栄養補給法は, 経口栄養法が18名（男性 5 名, 女性13名), 経腸栄養法が 8 名 (男性 1 名, 女性 7 名) であった。経腸栄養者の栄養剤は, MA-R2.0（クリニ コ $)^{59)}$, サンエット-SA (三和化学研究所) ${ }^{59)}$ であった。

\section{3) インフォームド・コンセント}

両調査の対象者は, インフォームド・コンセントの後 に，本人または家族（本人が意思の疎通が困難な場合は 家族のみ）から書面で調査への参加の同意が得られた者 である。インフォームド・コンセントの内容は, 本調査 の目的, 意義, 研究内容とその方法, 本調査によって受 けるメリットとデメリット，調査への参加中においても 自由意志により随時に調査を辞退することができること， 費用の負担は一切伴わないことなどについてである。

両研究は，美作大学研究倫理委員会によって承認を得 た（調査 $1 ： 2005$ 年 5 月19日承認，調査 $2 ： 2011$ 年 9 月 26日承認)。また, 本研究は, ヘルシンキ宣言の精神に 則り,「臨床研究に関する倫理指針（厚生労働省，2004 
年12月28日改正抒よび2008年 7 月31日改正)」に基づい て実施した。

\section{（２）食事調査および血液検査}

\section{1) 食事調査}

i ) 調查 1

1 回目を調査開始時の2006年 6 月 1 日から 6 月 30 日, 2 回目を同年の 12 月 1 日から 12 月 31 日に実施した。なお， 調査期間中は, いかなる介入も行っていない。栄養価計 算は, 各調査期間内の献立表と診療録により, 朝, 昼, 夕食の栄養素摂取量を栄養価計算ソフ（五訂増補日本 食品標準成分表／日本人の食事摂取基準2005年版対応 エクセル栄養君，株式会社建帛社）を用いて求めた。各 調査期間の栄養素摂取量は，1日あたりに換算した。な お，調査施設における献立および経腸栄養法の投与プラ ンは, 調査当時に使用していた日本人の食事摂取基準(以 下，食事摂取基準とする）2005年版の70歳以上身体活動 レベル I の推奨量 (RDA), 目安量 $(\mathrm{AI})$ および目標量 $(\mathrm{DG})^{60)}$ に従って作成されていた。経腸栄養者は, 個々 の活動度を考慮してエネルギー投与量が決定されていた。 したがって，たんぱく質，亜鉛や他の栄養投与量は，食 事摂取基準と異なる。

\section{ii ) 調查 2}

1 か月間（2011年11月14日～12月13日）の栄養素摂取 量は, 調査 1 と同様に算出して 1 日あたりに換算した。 なお, 調査 1 同様, 調査期間中はいかなる介入も行って いない。栄養素摂取量の算出に使用した栄養価計算ソフ 卜は, 調査 1 と同様である。なお, 施設で用いられてい る献立および経腸栄養法の投与プランは, 食事摂取基準 2010年版の70歳以上身体活動レベル I の推奨量（RDA）, 目安量 (AI) および目標量 $(\mathrm{DG})^{61)}$ に基づいて作成され ていた。経腸栄養者の投与量については, 調査 1 と同じ である。

\section{2 ）血液検査}

\section{i ) 調査 1}

1 回目, 2 回目ともに, 調査期間内の最終週の 2 日間 に血液検査を行った。血液検査の項目は, 白血球 (WBC) 赤血球 $(\mathrm{RBC})$, モモグロビン $(\mathrm{Hb})$ ，へマトクリット $(\mathrm{Ht})$, 総たんぱく質 $(\mathrm{TP})$, アルブミン $(\mathrm{Alb})$, 血清覀鉛, 鉄, 銅の濃度である。採血は，早朝空腹時が望ましいが，施 設において一度に多人数の対象者の採血を早朝の空腹時 に行うことは人的に困難であった。そのため, 亜鉛の日 内変動 ${ }^{62}$ を考慮して, 採血時刻は14時から15時の間に, 肘静脈，または手背ないし足背の表在静脈より行った。 なお， $\mathrm{WBC}, \mathrm{RBC}, \mathrm{Hb}, \mathrm{Ht}$ の測定は国立病院機構鳥取 医療センター (鳥取：鳥取) で行い, TP, Alb, 血清亜鉛, 鉄, 銅の濃度の測定は岡山医学検査センター（岡山：倉 敷）に委託した。亜鉛值の測定は原子吸光法で行われた。

\section{ii ）調査 2}

血中成分值の測定は, 調査 1 と同様に調査の最終週に
1 回実施した。採血時間, 採血部位も調査 1 と同様であ る。なお，血中成分值の測定は分析センター（岡山医学 検査センター）に委託した。血清亜鉛值の測定は調査 1 と同様である。

\section{(3) 統計処理}

結果はすべて平均值士標準偏差で示した。栄養素摂取 量および血液検査の統計処理は Mann-Whitney 検定,

Kruskal Wallis 検定を用い, 有意水準はすべて 5 \%未満 とした。また, 対象者の属性と GNRI 值, WBC, RBC, $\mathrm{Hb}, \mathrm{Ht}, \mathrm{TP}, \mathrm{Alb}$, 血清覀鉛, 鉄, 銅值の統計処理は, 単相関係数を用い有意水準はすべて $5 \%$ 未満とした。結 果の統計処理には, SPSS 22.0J for Windows（エス・ ピー・エス・エス株式会社）を使用した。

\section{3. 結 果}

\section{（1）GNRIリスク別における属性の比較}

\section{1) 調 査 1}

対象者の GNRI 值は, Bouillanne ら ${ }^{7)}$ に準じ, GNRI リスク別（リスクなし群：GNRI 值 > 98, 低リスク群 : GNRI 值 92 to $\leqq 98$, 中リスク群 : GNRI 值 82 to $<92$, 高 リスク群：GNRI 值＜82）に分類し，属性の比較を行っ た（table 2 ）。この結果, BMIにのみ有意差が認められ, リスクなし群に比して中リスク群は有意に低かった $(p<0.01)$ 。

GNRI 值91以下の中リスクおよび高リスクの 3 年生存 率は不良であるとの報告がある ${ }^{63)}$ 。そこで, GNRIリス クなしおよび低リスク（リスクなし・低リスク）群と中 リスク・高リスク（中・高リスク）の 2 群に分類して検 討した。この結果, リスクなし・低リスク群に比して, 中・高リスク群が有意に低かった項目は, 体重 $(p<$ $0.05), \mathrm{BMI}(p<0.01), \mathrm{BMR}(p<0.05)$ であり, 有 意に高かっ項目は要介護度であった $(p<0.01)$ 。

\section{2 ) 調 査 2}

調査 1 同様に, 対象者の GNRI リスク別における属性 の比較を table 2 に示した。体重, BMI, BMR, 要介護 度, 認知度に有意差が認められた。

体重は, リスクなし群に比して低リスク群, 中リスク 群，高リスク群において有意に低かった（すべて $p<$ 0.05)。BMIは, リスクなし群に比して, 中リスク群と

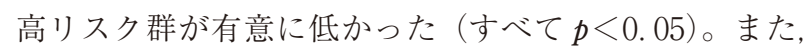
低リスク群に比して, 高リスク群は有意に低かった（ <0.01）。BMRは, リスクなし群に比して, 低リスク群, 中リスク群, 高リスク群において有意に低かった（すべ て $p<0.05)$ 。要介護度は, リスクなし群に比して高リ スク群で有意に高かった $(p<0.05)$ 。認知度は, リスク なし群に比して中リスク群で有意に高かった $(p<0.05)$ 。 また，低リスク群に比して，中リスク群で有意に高かっ た $(p<0.05)$ 。

調査 1 同様にリスクなし・低リスク群と中・高リスク 
Table 2 The characteristic of the subjects by the Geriatric Nutritional Risk Index

\begin{tabular}{|c|c|c|c|c|c|c|c|c|c|c|}
\hline \multirow[b]{2}{*}{ GNRI values ${ }^{* 1}$} & \multicolumn{5}{|c|}{ Survey 1} & \multicolumn{5}{|c|}{ Survey 2} \\
\hline & Whole & $\begin{array}{c}\text { No Risk 1) } \\
>98\end{array}$ & $\begin{array}{c}\text { Low Risk 2) } \\
92 \text { to } \leqq 98\end{array}$ & $\begin{array}{c}\text { Moderate Risk } 3 \text { ) } \\
82 \text { to }<92\end{array}$ & $\begin{array}{c}\text { Major Rrisk 4) } \\
<82\end{array}$ & Whole & $\begin{array}{c}\text { No Risk 1) } \\
>98\end{array}$ & $\begin{array}{c}\text { Low Risk 2) } \\
92 \text { to } \leqq 98\end{array}$ & $\begin{array}{c}\text { Moderate Risk 3) } \\
82 \text { to }<92\end{array}$ & $\begin{array}{c}\text { Major Rrisk 4) } \\
<82\end{array}$ \\
\hline $\bar{n}$ & 21 & 8 & 4 & 6 & 3 & 26 & 5 & 6 & 8 & 7 \\
\hline $\operatorname{Sex}^{* 2}$ & $\mathrm{M}: 3 \mathrm{~F}: 18$ & $\mathrm{M}: 0 \mathrm{~F}: 8$ & $\mathrm{M}: 0 \mathrm{~F}: 4$ & $\mathrm{M}: 3 \mathrm{~F}: 3$ & $\mathrm{M}: 0 \mathrm{~F}: 3$ & $\mathrm{M}: 6 \mathrm{~F}: 20$ & $\mathrm{M}: 3 \mathrm{~F}: 2$ & $\mathrm{M}: 0 \mathrm{~F}: 6$ & $\mathrm{M}: 1 \mathrm{~F}: 7$ & $\mathrm{M}: 2 \mathrm{~F}: 5$ \\
\hline Age & $83 \pm 7$ & $85 \pm 7$ & $86 \pm 1$ & $82 \pm 7$ & $76 \pm 6$ & $90 \pm 6$ & $84 \pm 8$ & $89 \pm 5$ & $92 \pm 5$ & $90 \pm 6$ \\
\hline Body Weight $(\mathrm{kg})$ & $42.7 \pm 6.3$ & $47.3 \pm 2.2$ & $39.8 \pm 9.6$ & $42.9 \pm 2.9$ & $33.8 \pm 3.1$ & $41.3 \pm 8.3$ & $54.0 \pm 6.3^{* 2,34}$ & $39.3 \pm 3.7$ & $39.4 \pm 5.9$ & $36.1 \pm 5.8$ \\
\hline Height $(\mathrm{cm})$ & $148.4 \pm 9.7$ & $147.2 \pm 5.3$ & $141.0 \pm 15.0$ & $154.7 \pm 10.5$ & $149.3 \pm 1.2$ & $145.8 \pm 9.2$ & $151.1 \pm 14.3$ & 139. $2 \pm 6.1$ & $144.9 \pm 5.5$ & $148.9 \pm 8.4$ \\
\hline IBW (kg) & $49.4 \pm 6.4$ & $48.3 \pm 3.2$ & $44.6 \pm 9.0$ & $53.8 \pm 7.4$ & $49.6 \pm 0.7$ & $47.8 \pm 6.1$ & $51.7 \pm 9.7$ & $43.5 \pm 3.7$ & $47.0 \pm 3.4$ & $49.7 \pm 5.7$ \\
\hline BMI & $19.4 \pm 2.7$ & $21.9 \pm 1.2^{\text {**3) }}$ & $19.8 \pm 0.7$ & $18.0 \pm 1.6$ & $15.2 \pm 1.3$ & $19.4 \pm 3.2$ & $23.9 \pm 2.7^{* 3,4)}$ & $20.3 \pm 1.3^{\text {m(4) }}$ & $18.7 \pm 1.9$ & $16.2 \pm 1.4$ \\
\hline BMR (kcal/day) & $888 \pm 134$ & $978 \pm 45$ & $824 \pm 199$ & $905 \pm 77$ & $700 \pm 64$ & $865 \pm 185$ & $1145 \pm 152^{* 2,34}$ & $814 \pm 76$ & $821 \pm 132$ & $757 \pm 132$ \\
\hline Level of Care & $3.4 \pm 1.4$ & $2.8 \pm 1.3$ & 2. $0 \pm 1.2$ & $4.5 \pm 0.5$ & $4.7 \pm 0.6$ & $3.6 \pm 1.1$ & $2.6 \pm 0.5^{\mathrm{k}(4)}$ & $3.2 \pm 1.2$ & $4.0 \pm 1.3$ & $4.1 \pm 0.7$ \\
\hline Grade of Bedriddenness & & & & & & $2.3 \pm 0.7$ & $2.0 \pm 0$ & $1.7 \pm 0.5$ & $2.5 \pm 0.8$ & $2.7 \pm 0.5$ \\
\hline Grade of Cognitive Function & & & & & & $2.6 \pm 0.8$ & $1.6 \pm 0.5^{* 3)}$ & $2.2 \pm 0.4^{* 3)}$ & $3.3 \pm 0.5$ & $2.9 \pm 0.7$ \\
\hline Type of Diet ${ }^{* 3}$ & $\begin{array}{c}\text { Regular : } 6 \\
\text { Rice Gruel : } 11 \\
\text { Enterally : } 4\end{array}$ & $\begin{array}{c}\text { Regular : } 4 \\
\text { Rice Gruel : } 4 \\
\text { Enterally : } 0\end{array}$ & $\begin{array}{c}\text { Regular : } 0 \\
\text { Rice Grue : } 4 \\
\text { Enterally : } 0\end{array}$ & $\begin{array}{c}\text { Regular : } 2 \\
\text { Rice Gruel : } 2 \\
\text { Enterally : } 2\end{array}$ & $\begin{array}{c}\text { Regular: } 0 \\
\text { Rice Gruel : } 1 \\
\text { Enterally : } 2\end{array}$ & $\begin{array}{c}\text { Regular: } 10 \\
\text { Rice Gruel : } 8 \\
\text { Enterally : } 8\end{array}$ & $\begin{array}{c}\text { Regular : } 3 \\
\text { Rice Gruel : } 2 \\
\text { Enterally : } 0\end{array}$ & $\begin{array}{c}\text { Regular : } 5 \\
\text { Rice Gruel : } 1 \\
\text { Enterally : } 0\end{array}$ & $\begin{array}{c}\text { Regular : } 2 \\
\text { Rice Gruel : } 3 \\
\text { Enterally : } 3\end{array}$ & $\begin{array}{c}\text { Regular : } 0 \\
\text { Rice Gruel : } 2 \\
\text { Enterally : } 5\end{array}$ \\
\hline
\end{tabular}

* 1 The Geriatric Nutritional Risk Index (GNRI) values calculeted according to the Bouillanne et al formula ${ }^{7}, \mathrm{GNRI}=[1.489 \times$ serum Albumin $($ Alb) $(\mathrm{g} /$ $\mathrm{dL}) \times 10]+[41.7 \times[$ Body Weight $(\mathrm{kg}) \div$ IBW $(\mathrm{kg})]]$. GNRI values were classified into four grades of nutrition-related risk : no risk (GNRI: $>98)$, low risk (GNRI: 92 to $\leqq 98)$, moderate risk (GNRI: 82 to $<92$ ), and major risk (GNRI: $<82)^{7}$. The average values of the characteristic were indicated by the GNRI classification (no risk, low risk, moderate risk, and major risk).

Each values is mean $\pm \mathrm{SD}$

* $2 \mathrm{M}$ means male and $\mathrm{F}$ means female.

$* 3$ The number shows the type of diet.

Significant difference: $*, p<0.05 ; * *, p<0.01$ (Kruskal Wallis test)

群の 2 群に分類して検討すると, リスクなし・低リスク 群に比して，中・高リスク群が有意に低かった項目は， 体重 $(p<0.05)$, BMI $(p<0.01), \operatorname{BMR}(p<0.05)$ で あり, 有意に高かった項目は, 要介護度 $(p<0.05)$, 寝 たきり度 $(p<0.01)$ ，認知度 $(p<0.01)$ であった。

\section{（2）GNRI リスク別における血中成分の比較}

\section{1) 調 査 1}

対象者の 1 または 2 回の血中成分值を GNRIリスク別 に示した (table 3$)$ 。この結果, Alb 值にのみ有意差が 認められ，リスクなし群に比して中リスク群は有意に低 かった $(p<0.01)$ 。

また，GNRIのリスクをリスクなし・低リスク群と 中・高リスク群の 2 群に分類して検討すると, リスクな し・低リスク群に比して中・高リスク群が有意に低かっ た血中成分は, $\mathrm{TP}, \mathrm{Alb}$, 鉄, 亜鉛值であった（すべて $p<0.01$ )。

\section{2 ) 調 査 2}

調査 1 同様に対象者の 1 回の血中成分值を GNRI リス ク別に示した（table 3 )。この結果，Alb 值にのみ有意 差が認められ, リスクなし群および低リスク群に比して 高リスク群は有意に低かった（それぞれ $p<0.05, p<$ 0. 01)。

また，調査 1 同様にリスクなし・低リスク群と中・高 リスク群の 2 群に分類して検討すると，リスクなし・低 リスク群に比して中・高リスク群が有意に低かった血中 成分は, $\mathrm{RBC}(p<0.05), \mathrm{Hb}(p<0.05), \mathrm{Ht}(p<0.05)$, $\mathrm{TP}(p<0.05), \mathrm{Alb}(p<0.01), \mathrm{A} / \mathrm{G}$ 比 $(p<0.05)$, 亜 鉛值 $(p<0.01)$ であった。

\section{（３）GNRI リスク別における栄養素摂取量の比較}

\section{1) 調 査 1}

対象者の栄養素摂取量は, 1 または 2 回目の各調査期 間の摂取量を 1 日あたりに換算し GNRIリスク別に比較 した。この結果，有意差の認められた栄養素はなかった。

\section{2 ) 調 査 2}

対象者の栄養素摂取量は, 調査 1 同様に調査期間の攝 取量を 1 日あたりに換算し GNRIリスク別に比較した。 この結果，有意差の認められた栄養素はなかった。

\section{（4）GNRI 值と属性および血中成分値の関係}

\section{1 ) 調 査 1}

対象者の GNRI 值の 1 または 2 回の算出值と属性（年 齢, 体重, 身長, IBW, BMI, BMR, 要介護度）およ び血中成分值 (WBC, RBC, Hb, Ht, TP, Alb, A/G 比, 鉄, 銅, 亜鉛）の 1 または 2 回の值との単相関を行い, 有意差の認められた項目のみ示した (table 4)。この結 果，GNRI 值との間に有意な正の相関が認められた項目 は, 体重 $(p<0.01)$, BMI $(p<0.01)$, BMR $(p<$ $0.05)$, TP $(p<0.01)$, Alb $(p<0.01), \mathrm{A} / \mathrm{G}$ 比 $(p<$ $0.05)$, 鉄 $(p<0.05)$, 垔鉛 $(p<0.01)$ であった。また, GNRI 值との間に有意な負の相関が認められた項目は, 要介護度であった $(p<0.01)$ 。

\section{2 ) 調 査 2}

調査 1 同様に，対象者の GNRI 值の算出值と属性（調 査 1 に寝たきり度と認知度を追加する）および血中成分 值との単相関を行い, 有意差の認められた項目のみ示し た（table 4)。この結果, GNRI 值との間に有意な正の 相関が認められた項目は，体重 $(p<0.01)$, BMI $(p<$ 
日本食生活学会誌 Vol.26 No.1 (2015)

Table 3 The classification of constituents in serum by the Geriatric Nutritional Lisk Index

\begin{tabular}{|c|c|c|c|c|c|c|c|c|c|c|}
\hline \multirow[b]{2}{*}{ GNRI values *1 } & \multicolumn{5}{|c|}{ Survey 1} & \multicolumn{5}{|c|}{ Survey 2} \\
\hline & Whole & $\begin{array}{c}\text { No Risk 1) } \\
>98\end{array}$ & $\begin{array}{c}\text { Low Risk 2) } \\
92 \text { to } \leqq 98\end{array}$ & $\begin{array}{c}\text { Moderate Risk } 3 \text { ) } \\
82 \text { to }<92\end{array}$ & $\begin{array}{c}\text { Major Rrisk 4) } \\
<82\end{array}$ & Whole & $\begin{array}{c}\text { No Risk 1) } \\
>98\end{array}$ & $\begin{array}{c}\text { Low Risk 2) } \\
92 \text { to } \leqq 98\end{array}$ & $\begin{array}{c}\text { Moderate Risk } 3 \text { ) } \\
82 \text { to }<92\end{array}$ & $\begin{array}{c}\text { Major Rrisk 4) } \\
\quad<82\end{array}$ \\
\hline$n$ & 21 & 8 & 4 & 6 & 3 & 26 & 5 & 6 & 8 & 7 \\
\hline $\mathrm{WBC}(/ \mu \mathrm{L})$ & $6048 \pm 1589$ & $5650 \pm 1106$ & $7825 \pm 1261$ & $5133 \pm 1343$ & $6567 \pm 2050$ & $6346 \pm 1497$ & $6860 \pm 1476$ & $5667 \pm 824$ & $6500 \pm 1514$ & $6386 \pm 1984$ \\
\hline $\operatorname{RBC}\left(10^{4} / \mu \mathrm{L}\right)$ & $401 \pm 76$ & $420 \pm 75$ & $370 \pm 113$ & $417 \pm 31$ & $362 \pm 96$ & $402 \pm 50$ & $453 \pm 47$ & $412 \pm 44$ & $368 \pm 48$ & $398 \pm 30$ \\
\hline $\mathrm{Hb}(\mathrm{g} / \mathrm{dL})$ & $11.9 \pm 2.3$ & $12.3 \pm 2.7$ & $11.1 \pm 2.3$ & $12.3 \pm 1.3$ & $11.1 \pm 3.2$ & $12.2 \pm 1.5$ & $13.9 \pm 1.4$ & $12.3 \pm 1.0$ & $11.2 \pm 1.4$ & $12.2 \pm 0.9$ \\
\hline Ht (\%) & $35.6 \pm 6.5$ & $37.3 \pm 7.5$ & $32.9 \pm 7.2$ & $36.7 \pm 4.0$ & $32.6 \pm 8.2$ & $36.9 \pm 4.5$ & $41.6 \pm 4.7$ & $37.7 \pm 3.3$ & $33.6 \pm 4.1$ & $36.8 \pm 3.0$ \\
\hline $\mathrm{TP}(\mathrm{g} / \mathrm{dL})$ & $7.0 \pm 0.6$ & $7.4 \pm 0.5$ & $7.3 \pm 0.3$ & $6.7 \pm 0.5$ & $6.2 \pm 0.2$ & $6.7 \pm 0.5$ & $6.9 \pm 0.4$ & $7.0 \pm 0.6$ & $6.6 \pm 0.3$ & $6.2 \pm 0.4$ \\
\hline $\operatorname{Alb}(g / d L)$ & $3.8 \pm 0.4$ & $4.1 \pm 0.2^{\text {w*33) }}$ & $3.9 \pm 0.1$ & $3.5 \pm 0.2$ & $3.3 \pm 0.5$ & $3.6 \pm 0.4$ & $4.1 \pm 0.3^{* 4)}$ & $3.9 \pm 0.2^{\text {*a*4) }}$ & $3.5 \pm 0.3$ & $3.2 \pm 0.2$ \\
\hline $\mathrm{A} / \mathrm{G}$ ratio & 1. $18 \pm 0.18$ & $1.28 \pm 0.16$ & $1.12 \pm 0.12$ & $1.11 \pm 0.19$ & $1.14 \pm 0.26$ & $1.20 \pm 0.24$ & $1.46 \pm 0.32$ & $1.24 \pm 0.15$ & $1.13 \pm 0.19$ & $1.07 \pm 0.13$ \\
\hline Iron $(\mu \mathrm{g} / \mathrm{dL})$ & $43 \pm 16$ & $50 \pm 18$ & $50 \pm 15$ & $34 \pm 6$ & $32 \pm 19$ & $57 \pm 22$ & $68 \pm 22$ & $61 \pm 26$ & $52 \pm 25$ & $50 \pm 13$ \\
\hline Copper $(\mu \mathrm{g} / \mathrm{dL})$ & $107 \pm 22$ & $119 \pm 19$ & $100 \pm 9$ & $103 \pm 15$ & $95 \pm 47$ & $124 \pm 19$ & $128 \pm 18$ & $130 \pm 20$ & $115 \pm 19$ & $127 \pm 20$ \\
\hline Zinc $(\mu \mathrm{g} / \mathrm{dL})$ & $85 \pm 17$ & $94 \pm 6$ & $91 \pm 16$ & $76 \pm 22$ & $68 \pm 7$ & $56 \pm 8$ & $65 \pm 8$ & $60 \pm 5$ & $54 \pm 5$ & $50 \pm 6$ \\
\hline
\end{tabular}

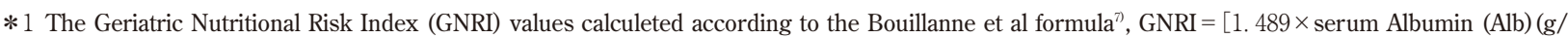
$\mathrm{dL}) \times 10]+[41.7 \times[$ Body Weight $(\mathrm{kg}) \div \mathrm{IBW}(\mathrm{kg})]]$

GNRI values were classified into four grades of nutrition-related risk: no risk (GNRI: $>98$ ), low risk (GNRI: 92 to $\leqq 98)$, moderate risk (GNRI: 82 to $<$ 92), and major risk (GNRI: $<82)^{7}$. The avereage value of the constituents in serum of the subjects were indicated by the GNRI classification (no risk, low risk, moderate risk, and major risk).

Each value is shown with mean and \pm SD.

Significant difference: $*, p<0.05 ; * *, p<0.01$ (Kruskal Wallis test)

Table 4 The correlation between Geriatric Nutritional Risk Index values and the characteristic, and between Geriatric Nutritional Risk Index values and constituent values in serum of the subjects

\begin{tabular}{|c|c|c|c|c|}
\hline & \multicolumn{2}{|c|}{ Survey 1} & \multicolumn{2}{|c|}{ Survey 2} \\
\hline & Correlation Coefficient & Regression Formula & Correlation Coefficient & Regression Formula \\
\hline Body Weight (kg) & $0.588 * *$ & $y=0.3914 x+6.5026$ & $0.652 * *$ & $y=0.5214 x-5.4897$ \\
\hline BMI & $0.849 * *$ & $y=0.2352 x-2.3216$ & $0.865 * *$ & $y=0.2662 x-4.4943$ \\
\hline BMR (kcal/day) & $0.545 *$ & $y=7.6601 x+180.59$ & $0.619 * *$ & $y=11.046 x-127.03$ \\
\hline Level of Care & $-0.555 * *$ & $y=-0.0821 x+10.966$ & $-0.470 *$ & $y=-0.0516 x+8.206$ \\
\hline Grade of Bedriddenness & & & $-0.535 * *$ & $y=-0.0344 x+5.3561$ \\
\hline Grade of Cognitive Function & & & $-0.647 * *$ & $y=-0.0504 x+7.1057$ \\
\hline $\mathrm{TP}(\mathrm{g} / \mathrm{dL})$ & $0.737 * *$ & $y=0.0467 x+2.6924$ & $0.637 * *$ & $y=0.0315 x+3.8389$ \\
\hline $\mathrm{Alb}(\mathrm{g} / \mathrm{dL})$ & $0.903 * *$ & $y=0.0374 x+0.3171$ & $0.862 * *$ & $y=0.034 x+0.5558$ \\
\hline $\mathrm{A} / \mathrm{G}$ ratio & $0.441 *$ & $y=0.0082 x+0.4202$ & $0.572 * *$ & $y=0.0128 x+0.0539$ \\
\hline Iron $(\mu \mathrm{g} / \mathrm{dL})$ & $0.520 *$ & $y=0.8664 x-37.455$ & $0.418 *$ & $y=0.8763 x-22.125$ \\
\hline $\operatorname{Zinc}(\mu \mathrm{g} / \mathrm{dL})$ & $0.610 * *$ & $y=1.0871 x-15.606$ & $0.739 * *$ & $y=0.5586 x+6.1284$ \\
\hline
\end{tabular}

The formulas show a single regression equation.

Significant difference: $*, p<0.05 ; * *, p<0.01$ (single regression analysis)

$0.01), \operatorname{BMR}(p<0.01), \operatorname{TP}(p<0.01)$, Alb $(p<$ $0.01), \mathrm{A} / \mathrm{G}$ 比 $(p<0.01)$, 鉄 $(p<0.05)$, 悪鉛 $(p<$ 0.01) であった。また, GNRI 值との間に有意な負の相 関が認められた項目は, 要介護度 $(p<0.05)$, 寝たきり 度 $(p<0.01)$, 認知度 $(p<0.01)$ であった。

\section{（５）血清亜鉛値と GNRI 值，属性および血中成分値と の関係}

\section{1) 調 査 1}

対象者の血清亜鉛值の 1 または 2 回の值と GNRI 值, 属性（年齢, 体重, 身長, IBW, BMI, BMR, 要介護度) および血中成分值 $(\mathrm{WBC}, \mathrm{RBC}, \mathrm{Hb}, \mathrm{Ht}, \mathrm{TP}, \mathrm{Alb}$,
$\mathrm{A} / \mathrm{G}$ 比, 鉄, 銅）の 1 または 2 回の值との単相関の結 果を示した (table 5 )。この結果, 血清亜鉛值との間に 有意な正の相関が認められた項目は, GNRI 值 $(p<$ $0.01)$, 体重 $(p<0.05), \mathrm{RBC}(p<0.05)$, $\mathrm{Ht}(p<$ $0.05)$, TP $(p<0.05)$, Alb 值 $(p<0.01)$ であった。

\section{2 ) 調 査 2}

調査 1 同様に，対象者の血清亜鉛值と GNRI 值，属性 （調査 1 に寝たきり度と認知度を追加）および血中成分 值との単相関の結果を示した (table 5 )。この結果，血 清亜鉛值との間に有意な正の相関が認められた項目は, GNRI 值 $(p<0.01)$, 体重 $(p<0.05)$, BMI $(p<0.05)$, BMR $(p<0.05)$, RBC $(p<0.05)$, Ht $(p<0.05)$, TP $(p$ 
Table 5 The correlation between serum zinc values and the characteristic, and between serum zinc values and constituent values in serum of the subjects

\begin{tabular}{l|c|c}
\hline \multirow{2}{*}{ Age } & Survey 1 & Survey 2 \\
\cline { 2 - 3 } Body Weight $(\mathrm{kg})$ & Zinc $(\mu \mathrm{g} / \mathrm{dL})$ & Zinc $(\mu \mathrm{g} / \mathrm{dL})$ \\
BMI & 0.250 & $-0.529 *$ \\
BMR $(\mathrm{kcal} / \mathrm{day})$ & $0.440 *$ & $0.466 *$ \\
$\mathrm{RBC}\left(10^{4} / \mu \mathrm{L}\right)$ & 0.390 & $0.470 *$ \\
$\mathrm{Ht}(\%)$ & 0.419 & $0.450 *$ \\
$\mathrm{TP}(\mathrm{g} / \mathrm{dl})$ & $0.450 *$ & $0.434 *$ \\
Alb $(\mathrm{g} / \mathrm{dL})$ & $0.448 *$ & $0.430 *$ \\
$\mathrm{~A} / \mathrm{G} \mathrm{ratio}$ & $0.517 *$ & $0.447 *$ \\
$\mathrm{GNRI}$ & $0.659 * *$ & $0.811 * *$ \\
\hline
\end{tabular}

Significant difference: $*, p<0.05 ; * *, p<0.01$ (single regression analysis)

Table 6 The analysis from the regression equation

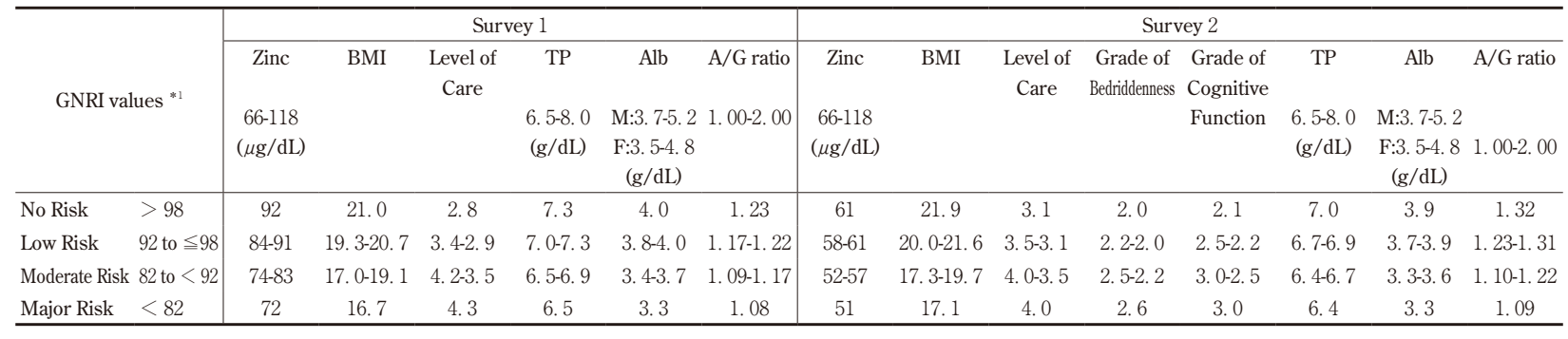

* 1 The Geriatric Nutritional Risk Index (GNRI) values calculeted according to the Bouillanne et al formula ${ }^{7}, \mathrm{GNRI}=[1.489 \times \operatorname{serum}$ Albumin $(\mathrm{Alb})(\mathrm{g} / \mathrm{dL})$ $\times 10]+[41.7 \times[$ Body Weight $(\mathrm{kg}) \div \mathrm{IBW}(\mathrm{kg})]]$

GNRI values were classified into four grades of nutrition-related risk: no risk (GNRI: $>98$ ), low risk (GNRI: 92 to $\leqq 98)$ ), moderate risk (GNRI: 82 to $<$ 92), and major risk (GNRI: $<82)^{\eta}$.

The values are drown from the analysis of the eight regression equations; between GNRI value and 8 dependent values; serum zinc, BMI, level of care, grade of bedriddenness, grade of cognitive function, TP, Alb, and A/G ratio.

$<0.05), \mathrm{Alb}(p<0.01), \mathrm{A} / \mathrm{G}$ 比 $(p<0.01)$ であった。 有意な負の相関が認められた項目は，年齢のみであった $(p<0.05)$ 。

\section{（6）GNRI 值と相関の得られた回帰式からの検討}

\section{1) 調 査 1}

GNRI 值と正相関および負の相関の得られた項目につ いて，回帰式を示した（table 4)。この回帰式から, GNRIリスク別に血清亜鉛，BMI，要介護度，TP，Alb， $\mathrm{A} / \mathrm{G}$ 比の值を示した（table 6)。この結果, GNRI 低リ スクにおいて，血清亜鉛值，BMI，TP, Alb 值, A/G 比が基準值を上回ることが認められた。

\section{2 ) 調 査 2}

GNRI 值と正相関および負の相関の得られた項目につ いて，調査 1 同様に回帰式を示した（table 4)。この回 帰式から，GNRIリスク別に血清亜鉛，BMI，要介護度， 寝たきり度, 認知度, $\mathrm{TP}, \mathrm{Alb}, \mathrm{A} / \mathrm{G}$ 比の值を示した (table 6 )。この結果，GNRI 低リスクに拈いて，BMI，
$\mathrm{TP}, \mathrm{Alb}$ 值， $\mathrm{A} / \mathrm{G}$ 比が基準值を上回ることが認められた。

\section{3 ）調査 1 および調査 2 をまとめて}

2 つの調査の散布図が同様の傾向を示したため，2つ の調査をまとめた回帰式についても検討した。この回帰 式から, GNRIリスク別に血清亜鉛, BMI, 要介護度, 寝たきり度，認知度， TP， Alb， A/G 比の值を示した (table 7 )。この結果, GNRI 低リスクにおいて血清覀 鉛值, BMI, TP, Alb 值, $\mathrm{A} / \mathrm{G}$ 比が基準值を上回るこ とが認められた。

\section{4. 考察}

著者らは, 亜鉛の栄養状態によって Alb, BMI, 要介 護度, 寝たきり度, 認知度が変動することを明らかにし た ${ }^{54)}$ 。そこで, 本研究では, 亜鉛の栄養状態で変化し, ADL を決定する要因でもある血清アルブミン值, BMI, 寝たきり度, 認知度を GNRIで評価した。そして，ADL を良好に維持するその值の設定を試みた。 
日本食生活学会誌 Vol.26 No.1 (2015)

Table 7 (Survey1 plus Survey 2) The analysis from the regression equation

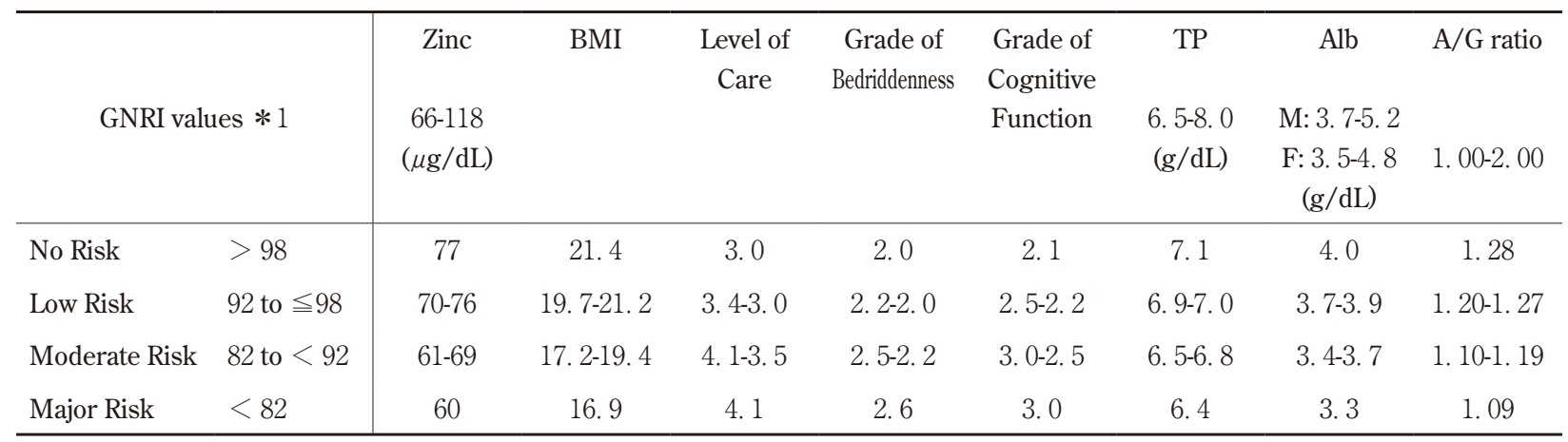

* 1 The Geriatric Nutritional Risk Index (GNRI) values calculeted according to the Bouillanne et al formula ${ }^{7}, \mathrm{GNRI}=[1.489 \times \operatorname{serum} \mathrm{Albumin}(\mathrm{Alb})(\mathrm{g} / \mathrm{dL})$ $\times 10]+[41.7 \times[$ Body Weight $(\mathrm{kg}) \div \mathrm{IBW}(\mathrm{kg})]]$

GNRI values were classified into four grades of nutrition-related risk : no risk (GNRI: $>98$ ), low risk (GNRI: 92 to $\leqq 98)$ ), moderate risk (GNRI: 82 to $<$ 92), and major risk (GNRI: $<82)^{7}$.

The values are drown from the analysis of the eight regression equations based on combined survey 1 and survey 2; between GNRI value and 8 dependent values; serum zinc, BMI, level of care, grade of bedriddenness, grade of cognitive function, TP, Alb, and A/G ratio.

\section{（1）GNRIリスク別における属性の比較}

対象者の GNRI リスク別に扔ける属性の比較において, 有意差が認められたのは，第 1 調査における $\mathrm{BMI}$ ，第 2 調査に扔ける体重，BMI，BMR，要介護度䇽よび認 知度であった（table 2)。つまり，GNRIのリスクが高 まるほど, 要介護度および認知度の上昇（悪化）にとも なう介護の必要度が増加することが認められた。要介護 度が上がると，GNRIの高リスクの割合が増えることや ${ }^{64}$, GNRI 值と ADL スコアとの間には，有意な負の相関関 係にあること敫が報告されている。このことから，高齢 者の ADLの指標である要介護度の重症化を防ぐためには, GNRI によるリスク評価が重要であるといえる。

GNRI 值91以下の中高リスクの 3 年生存率は不良であ るとの報告がある汪。そこで, GNRIリスクなし・低リ スク群と中・高リスク群の 2 群に分類して検討した。 GNRIのリスクなし・低リスク群に比して，中・高リス ク群は調查 1 , 調查 2 ともに, 体重, BMI, BMR が有 意に低下し，要介護度が有意に上昇（悪化）していた。 さらに，調査 2 においては，寝たきり度，認知度におい ても，中・高リスク群がリスクなし・低リスク群に比し て有意に高かった。したがって，GNRIの低リスクまで の段階に拉いて，栄養ケアの介入をすることが要介護度， 寝たきり度, 認知度の重症化に歯止めをかけることにな ると考えられる。

\section{（2）GNRIリスク別における血中成分值の比較}

対象者の GNRI リスク別に扮ける血中成分值の比較に 扔いて, 調查 1 抢よび調查 2 とも Alb 值以外に有意差の 認められた項目はなかった（table 3)。しかし, GNRI のリスクをリスクなし・低リスク群と中・高リスク群の 2 群に分類して検討すると, リスクなし・低リスク群に 比して中・高リスク群は, TP, Alb と血清亜鉛值が有意 に低下寸ることが調查 1 , 調査 2 に共通して認められた。
したがって，GNRIの中・高リスク者では，たんぱく質 の栄養と亜鉛の栄養状態の低下が示された。

\section{（3）GNRIリスク別における栄養素摂取量の比較}

対象者の GNRI リスク別に扔ける栄養素摂取量の比較 において，有意差の認められた栄養素はなかった。しか し，GNRIのリスクは，摂食障害や経口摂取率の低下に よって高まるとの報告がある ${ }^{10,65)}$ 。本研究の結果から， GNRI の中・高リスクにのみ経腸栄養者が認められた。 つまり, 経口摂取の維持が GNRI のリスク上昇を防ぐこ とにつながると考えられる。

\section{（4）GNRI 值と属性および血中成分値の関係}

GNRI 值と属性㧍よび血中成分值との相関関係を検討 した結果, 調查 1 , 調查 2 とも同じ傾向が認められた (table 4)。つまり，GNRI 值と正の相関の認められた 項目は, 体重, BMI, BMR, TP, Alb 值, A/G 比, 鉄, 亜鉛值であり，負の相関が認められたのは要介護度で あった。また, 調查 2 においては, 寝たきり度と認知度 においても負の相関が認められた。GNRI 值と血清亜鉛 值との間の相関係数は，Alb，BMI，TPに続く高い相関 係数であった。GNRI 值と TP, Alb 值との間には正相関 が認められておりり ${ }^{66)}$, BMI にも同様の相関が報告されて いる ${ }^{67}$ 。また, GNRI 值との間に正相関のあった BMI, 体重, TP, Alb 值は, これまでの著者らの研究より血清 亜鉛值とも関連が認められている ${ }^{68)}$ 。さらに，著者らは， 亜鉛の栄養状態が低下するほど認知度の悪化を認めてお $\eta^{54)}$ ，認知度と GNRI 值との関連性が判明し注目に值す る結果となった。認知症を有する高齢者は, 体重減少や 栄養障害を起こしやすいことが報告されている ${ }^{69}$ 。した がって, 本研究の結果から認知度の進行を GNRI 值で評 価することも可能であると考えられる。 


\section{（5）血清业鉛值と GNRI 值，属性および血中成分値と の関係}

血清亜鉛值は, 調查 1 に扔いて体重, $\mathrm{RBC}, \mathrm{Ht}, \mathrm{TP}$ Alb さらに GNRI 值と有意な正相関が認められている (table 5 )。調査 2 については, 調査 1 で相関が認めら れた項目に加えて BMI，BMR，A/G 比に抢いて有意な 正相関が観察された（table 5 )。血清亜鉛值と GNRI 值

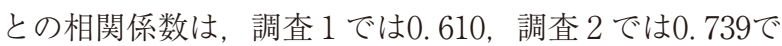
あり，どちらも有意な正の相関が認められた。したがっ て, 本研究の結果から, GNRI 值は, 亜鉛の栄養状態と の関連性が強く, 亜鉛の栄養状態を判定する有用な指標 になることが示唆された。今後，亜鉛の栄養状態を高め ることによって，GNRI の改善度を検討することが課題 である。

著者らの研究より, Alb 值と血清亜鉛值との間には正 相関が認められ ${ }^{522}$ ，ADL との間には負の相関があること を報告した ${ }^{68)}$ 。また，血清亜鉛值は，ADL との関連があ ることをすでに報告している ${ }^{54)}$ 。高齢者の ADL の維持 には筋肉量も関与することが認められているが，本研究 の結果から ADL 維持には筋肉量と密接に関連する BMI の影響も考慮する必要があると考えられる。

\section{（6）GNRI 值と相関の得られた回帰式からの検討}

高齢者の $\mathrm{ADL}$ 維持にかかわる要介護度, 寝たきり度, 認知度について GNRIのリスクと亜鉛の栄養状態から検 討した。また， BMI，TP，Alb 值， A/G 比の基準值と の関連性を検索した（table 6 )。本研究では, GNRI 值 と属性㧍よび血中成分の単相関を検討した散布図が調查 1, 調査 2 とも同様の傾向を示したため, 2 つの調査を まとめた回帰式についても検討した（table 7 )。この結 果，GNRI 低リスクに扔いて血清亜鉛值，BMI，TP， Alb 值， $\mathrm{A} / \mathrm{G}$ 比が基準值を上回ることが認められた。本 研究に打いても, 調査 1 (table 6), 調査 2 (table 6), そして調查 1 と調查 2 を合わせた table 7 の結果から GNRI 低リスクの下限値 GNRI 值92を見出した。そして, この值に扔いては，BMI およびたんぱく質栄養の指標 である $\mathrm{TP}$, Alb 值，A/G 比が基準值を上回り良好な值 となる。先行研究によると, GNRI は生命予後の指標に なるとの報告がある ${ }^{64)}$ 。日本人を対象とした GNRI 值に 関する報告によると，GNRI のカットオフ值は，90との 指摘があり ${ }^{70)}, 90$ 未満だと生命予後不良であることや ${ }^{70)}$ GNRI 值91以下の中高リスクの 3 年生存率は不良である との報告もある ${ }^{63)}$ 。さらに，低 GNRI 值は，感染が根底 になくても死亡率や罹患率のリスクと強く関連すること が報告されている7 。これらの先行研究からも，本研究 で得られた高齢者の ADLを良好に維持する指標となる GNRI 值は92，つまり低リスクの下限には妥当性がある。 以上のことから，GNRIによって，亜鉛の栄養状態で 変化する要介護度, 寝たきり度, 認知度, BMI, TP, $\mathrm{Alb}$ 值，A/G 比の評価が可能である。高齢者の $\mathrm{ADL}$ を
規定する要介護度, 寝たきり度, 認知度などの ADLの 因子を良好に維持するためには，GNRI 值92を上回る必 要がある。これに要する血清亜鉛值は基準值以上に維持 する必要性が示された。

\section{（7）本研究の限界}

本研究の限界として，対象者数が多くないことがあげ られる。調査 1 は 1 施設の要介護高齢者, 調查 2 は 2 施 設の要介護高齢者を対象としており, 調查 1,2 ともに, 年齢が異なる集団を対象にしていて対象者年齢には開き がある。また共通の結果がすべての調査項目で得られて いない。しかしながら，調查時期が異なるにもかかわら ずADL と GNRI 值との間の関連性においては同様の傾 向が認められた。また，本研究より高齢者の ADLを良 好に維持するには，GNRI 值92を上回ることが示されて おり，対象施設㧍よび対象者数を増やして本研究で得ら れた GNRI 值92の妥当性に関する詳細な調査が望まれる。 な押, 本研究の一部は, 日本食生活学会第 48 回大会 (平 成26年 5 月 24 日，東京）にて発表した。

\section{5. 要 約}

本研究では，亜鉛の栄養状態で変化し，ADLを決定 する要因でもある血清アルブミン值，BMI，寝たきり度， 認知度を GNRI で評価した。そして，ADLを良好に維 持するその值の設定を試みた。

この結果, GNRI のリスクなし・低リスク群に比して 中・高リスク群は調査 1 , 調査 2 ともに, 体重, BMI,

BMR, TP, Alb, 血清亜鉛值が有意に低下し, 要介護度 が有意に上昇していた。また，調査 2 においては，寝た きり度, 認知度においても，中・高リスク群がリスクな し・低リスク群に比して有意に高かった。

GNRI 值と正の相関の認められた項目は, 体重, BMI, BMR, TP, Alb 值, $\mathrm{A} / \mathrm{G}$ 比, 血清鉄掞よび监鉛值であり, 負の相関が認められたのは要介護度であった。また, 調 查 2 においては, 寝たきり度と認知度に扔いても負の相 関が認められた。

相関の得られた項目について回帰式から各値を求める と，GNRI 低リスクは血清亜鉛值，BMI，TP，Alb 值， $\mathrm{A} / \mathrm{G}$ 比が基準值を上回ることが認められた。

以上のことから，GNRIによって，亜鉛の栄養状態で 変化する要介護度, 寝たきり度, 認知度, BMI, TP, Alb 值，A/G 比の評価が可能である。高齢者の ADL の 因子である要介護度, 寝たきり度, 認知度を良好に維持 するためには，GNRI 值92を上回る必要があり，これに 要する血清亜鉛值は基準値以上に維持することが必要で ある。

\section{謝 辞}

本稿作成にあたり，本研究にご協力いただきました特 別養護老人ホーム，老人保健施設の利用者の皆様，採血 
等にご協力いただきました職員の皆様に深く感謝いたし ます。

\section{文献}

1）厚生労働統計協会：国民衛生の動向 2014/2015一厚生 の指標 増刊, 61，51 (2014)

2) Detsky AS, McLaughlin JR, Baker JP: What is subjective global asessment of nutritional status?, JPEN J Parenter Enteral Nutr, 11, 8-13 (1987)

3 ) Kalantar-Zadeh k, Kopple JD, Block G, Humphreys MH: A malnutrition-inflammation score is correlated with morbidity and mortality in maintenance hemodialyisis patients, $A m \mathrm{~J}$ Kidney Dis, 38, 1251-1263 (2001)

4) Rubenstein LZ, Harker JO, Salva A, Guigoz Y, Vellas B: Screening for undernutrition in geriatric practice: developing the short-form mini-nutritional assessment (MNA-SF), $J$ Gerontol A Biol Sci Med Sci, 56, M366-M372 (2001)

5 ) Reilly HM, Martineau JK, Moran A, Kennedy H: Nutritional screening-evaluation and implementation of a simple Nutrition Risk Score, Clin Nutr, 14, 269-273 (1995)

6 ) Stratton RJ, Hackston A, Longmore D, Dixon R, Price S, Stroud M, King C, Elia M: Malnutrition in hospital outpatients and inpatients: prevalence, concurrent validity and ease of use of the 'malnutrition universal screening tool' ('MUST") for adults, Br J Nutr, 92, 799-808 (2004)

7 ) Bouillanne O, Morineau G, Dupont C, Coulombel I, Vincent JP, Nicolis I, Benazeth S, Cynober L, Aussel C: Geriatric Nutritional Risk Index: a new index for evaluating at-risk elderly medical patients, Am J Clin Nutr, 82, 777-783 (2005)

8 ) Ferguson M, Capra S, Bauer J, Banks M: Development of a valid and reliable malnutrition screening tool for adult acute hospital patients, Nutrition, 15, 458-464 (1999)

9) Yamada K, Furuya R, Takita T, Maruyama Y, Yamaguchi Y, Ohkawa S, Kumagai H: Simplified nutritional screening tools for patients on maintenance hemodialysis, Am J Clin Nutr, 87, 106-113 (2008)

10) Cereda E, Vanotti A: Short dietary assessment improves muscle dysfunction identification by Geriatric Nutritional Risk Index in uncomplicated institutionalised patients over 70 years old, Clin Nutr, 27, 126-132 (2008)

11) Cereda E, Vanotti A: The new Geriatric Nutritional Risk Index is a good predictor of muscle dysfunction in institutionalized older patients, Clin Nutr, 26, 78-83 (2007)

12) Cereda E, Pedrolli C, Zagami A, Vanotti A, Piffer S, Opizzi A, Rondanelli M, Caccialanza R: Nutritional screening and mortality in newly institutionalised elderly: a comparison between the geriatric nutritional risk index and the mini nutritional assessment, Clin Nutr, 30, 793-798 (2011)

13）大荷満生 : 高齢者の栄養評価, 静脈経腸栄養, 22, 439445 (2007)

14) Cereda Em,Pedrolli C: The use of the Geriatric Nutritional Risk Index (GNRI) as a simplified nutritional screening tool, Am J Clin Nutr, 87, 1996-1967 (2008)

15) Park JH, Kim SB, Shin HS, Jung YS, Rim H: Geriatric Nutritional Risk Index may be a significant predictor of mortality in korean hemodialysis patients: a single center study, Ther Apher Dial, 16, 121-126 (2012)
16) Cereda E, Limonta D, Pusani C, Vanotti A: Assessing elderly at risk of malnutrition: The new Geriatric Nutritional Risk Index versus Nutritional Risk Index, Nutrition, 22, 680682 (2006)

17) Cereda E, Pedrolli C, Zagami A, Vanotti A, Piffer S, Faliva M, Rondanelli M, Caccialanza R: Nutritional risk, functional status and mortality in newly institutionalised elderly, $\mathrm{Br} \mathrm{J}$ Nutr, 110, 1903-1909 (2013)

18) Cerda E, Pedrolli C: The geriatric nutritional risk index, Curr Opin Clin Nutr Metab Care, 12, 1-7 (2009)

19) Cereda E, Pusani C, Limonta D Vanotti A: The ability of the geriatric nutritional risk index to assess the nutritional status and predict the outcome of homecare resident elderly: a comparison with the mini nutritional assessment, Br J Nutr, 102, 563-570 (2009)

20）倉澤隆平, 久堀周治郎, 上岡洋晴, 岡田真平, 松村興 広：長野県北御牧村村民の血清亜鉛濃度の実態, Biomed Res Trace Elem, 16, 61-65 (2005)

21) Mertz W: The role of trace elements in the aging process, Prog Clin Biol Res, 326, 229-240 (1990)

22) Pennington JA, Young BE: Total diet study nutritional elements, 1982-1989, J Am Diet Assoc, 91, 179-183 (1991)

23) Murphy P, Wadiwala I, Sharland DE, Rai GS: Copper and Zinc levels in healthy and sick elderly, J Am Geriatr Soc, 33, 847-849 (1985)

24）齋藤昇：高齢入院患者の血清銅／亜鉛比の検討, Biomed Res Trace Elem, 16，258-260 (2005)

25）岡田淳：裖瘡患者における血清覀鉛の動態, 微量金属代謝, 1，43-47 (1975)

26）系川嘉則：高齢者の微量元素欠乏症とその臨床の実際, 日医師会誌，129，635-638（2003）

27) Yanagisawa $\mathrm{H}$, Nodera M: Zinc physiology and clincal practice, Biomed Res Trace Elem, 18, 3-9 (2007)

28）岡田正, 高木洋治, 根津理一郎：亜鉛と臨床, Pharma Medica, 4 , 45-51 (1986)

29) Chasapis CT, Loutsidou AC, Spiliopoulou CA, Stefanido ME: Zinc and human health: an update, Arch Toxicol, 86, 521534 (2012)

30) Bhatnagar S, Taneja S: Zinc and congnitive development, BrJ Nutr, 85, S139-S145 (2001)

31) Ukita T, Oidov B, Kawada E, Ohyama Y, Morita T, Tamura J: Serum zinc deficiency increases susceptibility to infection in older patients who have long-term hospitalizations, Biomed Res Trace Elem, 19, 260-264 (2008)

32）上瀬英彦：在宅高齢患者における血清亜鉛の検討，日臨 内科医会誌，14，21-25（1999）

33) Ueda C, Takaoka T, Sarukura N, Matsuda K, Kitamura Y, Toda N, Tanaka T, Yamamoto S, Takeda N: Zinc nutrition in healthy subjects and patients with taste impairment from the view point of zinc ingestion, serum zinc concentration and angiotensin converting enzyme activity, Auris Nasus Larynx, 33, 283-288 (2006)

34) Christensson L, Unosson M, Ek AC: Malnutrition in elderly people newly admitted to a community resident home, J Nutr Health Aging, 3, 133-139 (1999)

35) Kerstetter JE, Holthausen BA, Fitz PA: Malnutrition in the institutionalized older adult, J Am Diet Assoc, 92, 1109-1116 (1992) 
36) Chen CC, Schilling LS, Lyder CH: A concept analysis of malnutrition in the elderly, J Adv Nurs, 36, 131-142 (2001)

37) Lesourd BM: Nutrition and immunity in the elderly: modification of immune responses with nutritional treatments, Am J Clin Nutr, 66, 478S-484S (1997)

38) Lesourd BM: Protein malnutrition: major cause of immunodeficiency in the elderly, Age Nutr, 1, 132-138 (1990)

39) Lesourd B: Protein undernutrition as the major cause of decreased immune functions in the elderly: clinical and functional implications, Nutr Rev, 53, S86-S94 (1995)

40) Lesourd BM, Meaume S: Cell mediated immunity changes in ageing,relative importance of cell subpopulation switches and of nutritional factors, Immunol Lett, 40, 235-242 (1994)

41) Lesourd BM, Salvatore R, Frigard B: Normal and pathologic immunological aging: the role of nutritional factors, Med Hyg, 51, 1663-1666 (1993)

42) Chandra RK: Nutrition is an important determinant of immunity in old age, Prog Clin Biol Res, 321-334 (1990)

43) Lesourd BM: Ageing and malnutrition: two causes of immunodeficiency in the elderly, Karthula Acct Aupelf, 646657 (1991)

44) Bernstein LH, Shaw-Stiffel TA, Schorow M, Brouillette R: Financial implications of malnutrition, Clin Lab Med, 13, 491507 (1993)

45) Mowé M, Bøhmer T, Kindt E: Reduced nutrition status in an elderly population $(>70 \mathrm{yr})$ is probable before disease and possibly contribute to the development of disease, Am J Clin Nitr, 59, 317-324 (1994)

46) Reilly JJ Jr, Hull SF, Albert N, Waller A, Bringardener S: Economic impact of malnutrition: A model system for hospitalized patients, JPEN J Parenter Enteral Nutr, 12, 371376 (1988)

47）松田朗：在宅老人患者の栄養管理に関する研究報告書, 国立医療・病院管理研究所, 国立健康 · 栄養研究所 (1996)

48）松田朗：高齢者の栄養管理サービスに関する研究報告書, 国立医療・病院管理研究所, 国立健康 ·栄養研究所 (1998)

49) Chandra RK, Joshi PAB, Woodford G, Chandra S: Nutrition and immune competence of the elderly. Effect of short term nutritional supplementation on cell mediated immunity and lymphocyte subsets, Nutr Res, 2, 223-232 (1982)

50) Lesourd BM, Favre-Berrone M, Thiollet M: Immunostimulated action of a complete oral supplementation in undernourished elderly patients, Age Nutr, 1, 41-51 (1990)

51) Chandra PK, Chandra S, Gupta S: Antibody affinity and immune complexes after immunization with tetanus toxoid in protein-energy malnutrition, Am J Clin Nutr, 40, 131-134(1984)

52）小坂和江, 小西吉裕, 山下佐知子, 菊永茂司：施設入所 要介護高齢者における亜鉛摂取量と血清中亜鉛值および関 連成分值に関する検討, 日本食生活学会誌, 23, 207-216(2013)

53）小坂和江, 小西吉裕, 菊永茂司：施設入所要介護高齢者 における Body Mass Index, 日常生活動作, 要介護度の違 いによる亜鉛栄養状態の変動, Biomed Res Trace Elem, 23,
208-216 (2012)

54) Kosaka K, Yamashita S, Ando C, Endo Y, Taniguchi K, Kikunaga S: Relationships among body mass index, activities of daily living and zinc nutritional status in disabled elderly patients in nursing facilities. J. Nutr. Sci. Vitaminol, 59, 420430 (2013)

55）聖隷三方原病院・コア栄養管理チーム：栄養ケアマネジ メントマニュアル, 医歯薬出版, 東京, p. 3-14 (2003)

56）厚生労働省：要介護認定, [Online]. Available: http:// www.mhlw.go.jp/seisakunitsuite/bunya/hukushi_kaigo/ kaigo_koureisha/nintei/index.html

57）日本栄養士会：経腸栄養食品（剂）便覧2009, 文光堂, 東京, p.67 (2009)

58）厚生労働省：介護と高齢者福祉, [Online]. Available: http://www.mhlw.go.jp/topics/kaigo/kentou/15kourei/ sankou $4 . h$ tml

59）日本栄養士会：経腸栄養製品（剤）便覧2011, 文光堂, 東京, p.154, 164 (2011)

60）厚生労働省：日本人の食事摂取基準（2005年版），第一出 版，東京，p.28-202（2005）

61）厚生労働省：日本人の食事摂取基準（2010年版）, 第一出 版, 東京, p.43-233 (2009)

62）高木洋治：微量元素の異常と評価方法, 栄評治, 19, 917 (2002)

63) Cereda E, Zagami A, Vanotti A, Piffer S, Pedrolli C: Geriatric Nutritional Risk Index and overall-cause mortality prediction in institutionalised elderly: A 3 -year survival analysis, Clin Nutr, 27, 717-723 (2008)

64）坂井誠, 榎本武郎, 須長典子, 関根めぐみ, 行部亮子： 要介護高齢者に掞ける高齢者栄養りスク指数（Geriatric Nutritional Risk Index）を用いた栄養評価の検討，JMC，65, 114-121 (2009)

65) Cereda E, Pusani C, Limonta D, Vanotti A: The association of geriatric nutritional risk index and total lymphocyte count with short-term nutrition-related complications in institutionalised elderly, J Am Coll Nutr, 27, 406-413 (2008)

66) Duran Alert P, Mila Villarroel R, Formiga F, Virgili Casas N, Vilarasau Farre C: Assessing risk screening methods of malnutrition in geriatric patients; Mini Nutritional Assessment (MNA) versus Geriatric Nutritional Risk Index (GNRI), Nutr Hosp, 27, 590-598 (2012)

67）小松由美, 多田弘子, 鈴木昌幸, 大河原晋：血液透析症 例に扔ける geriatric nutritional risk index（GNRI）の臨床的 意義に関する検討，山形県病医誌，46，39-43（2012）

68）菊永茂司, 小坂和江：高齢者に扔ける亜鉛の栄養状態と 身体機能，Trace Nutrients Research, 30, 101-109（2013）

69）山下一也, 小林祥泰 : 要介護高齢者の認知機能と栄養, Geriatric Medicine, 39, 1091-1094（2001）

70）加藤陽子, 奥野仙二, 山本忠司, 石村栄治：新しい栄養 関連指標一Geriatric Nutritional Risk Index（GNRI）につい て一, 大阪透析研会誌，27，77-81（2009） 